ГАЛУЗЕВИЙ АСПЕКТ РОЗВИТКУ НАЦІОНАЛЬНОГО ГОСПОДАРСТВА

UDC 502/504-048.35:330.111.4:332.13(477)

DOI: $10.25140 / 2411-5215-2018-1(13)-98-104$

\author{
Olha Popelo
}

\title{
ANALYSIS OF THE LEVEL OF ECOLOGICAL SPHERE MODERNIZATION AS A COMPONENT OF THE PRODUCTIVE FORCES MODERNIZATION OF THE UKRAINE REGIONS
}

\section{Ольга Попело \\ АНАЛІЗ РІВНЯ МОДЕРНІЗАЦЙНОГО СТАНУ ЕКОЛОГІЧНОЇ СФЕРИ ЯК СКЛАДОВОЇ МОДЕРНІЗАЦЇ̈ ПРОДУКТИВНИХ СИЛ РЕГІОНІВ УКРАЇНИ}

Ольга Попело

\section{АНАЛИЗ УРОВНЯ МОДЕРНИЗАЦИОННОГО СОСТОЯНИЯ ЭКОЛОГИЧЕСКОЙ СФЕРЫ КАК СОСТАВЛЯЮЩЕЙ МОДЕРНИЗАЦИИ ПРОИЗВОДИТЕЛЬНЫХ СИЛ РЕГИОНОВ УКРАИНЫ}

The article analyzes the level of modernization of the ecological sphere. The ranking of regions of Ukraine was conducted, as a result of which four groups of regions allocated: regions with crisis, critical, satisfactory and favorable level of modernization of the ecological sphere. The rating of dynamic changes of this indicator is given. The main priorities of the modernization of the environmental sphere are considered, among them: ecologically directed structural restructuring of the economy, support and development of high-tech, environmentally safe and resource-saving industries, application of new tools of environmental policy, ensuring information openness processes of adoption and implementation of ecological, economic and managerial decisions.

Keywords: modernization; productive forces; ecological state; region; globalization.

Fig.: 1. Table: 2. References: 7.

У статті здійснено моніторинг рівня модернізаційного стану екологічної сфери. Проведено ранжування регіонів України, у результаті якого виділено чотири групи регіонів: регіони з кризовим, критичним, задовільним та сприятливим рівнем модернізачійного стану екологічної сфери. Наведено рейтингову оцінку динамічних змін даного показника. Розглянуто основні пріоритети модернізаиї екологічної сфери, серед яких: екологічно спрямована структурна перебудова економіки, підтримка та розвиток високотехнологічних, екологічно безпечних і ресурсозберігаючих виробництв, застосування нових інструментів екологічної політики, забезпечення інформачійної відкритості процесів ухвалення і реалізації еколого-економічних та управлінських рімень.

Ключові слова: модернізація; продуктивні сили; екологічний стан; регіон; глобалізація.

Рис.: 1. Табл.: 2. Бібл.: 7.

В статье осуществлен мониторинг уровня модернизационного состояния экологической сферы. Проведено ранжирование регионов Украины, в результате которого выделено четыре группы регионов: регионы с кризисным, критическим, удовлетворительным и благоприятным уровнем модернизационного состояния экологической сферы. Приведено рейтинговую оценку динамических изменений данного показателя. Рассмотрены основные приоритеты модернизачии экологической сферы, среди которых: экологически направленная структурная перестройка экономики, поддержка и развитие высокотехнологичных, экологически безопасных и ресурсосберегающих производств, применения новых инструментов экологической политики, обеспечения информационной открытости прочессов принятия и реализации эколого-экономических и управленческих решений.

Ключевые слова: модернизация; производительные силь;; экологическое состояние; регион; глобализация.

Рис.: 1. Табл.: 2. Библ.: 7.

JEL Classification: O130, R130, R220

Problem statement. In today's globalization conditions, there are significant regional differences in the environmental load caused by rapid economic growth and rising levels of population consumption. Environmental problems are very acute for Ukraine, they are related to the emission of pollutants into the air, the accumulation of toxic waste, the preservation of a significant proportion of untreated wastewater entering the water bodies.

Analysis of recent research and publications. Environmental issues and issues of environmental management devoted a lot of scientific works of domestic and foreign scientists, including: I. K. Bistryakova, B. V. Burkinskoho, J. Grosmana, B. M. Danylyshyna, G. Daley, A. B. Kachynskoho, V. S. Kravtsiv, A. Kruegera, J. Meudouza, L. G. Melnika, T. Y. Tunici, J. Frankelya and others.

(C) Попело О. В., 2018 
ГАЛУЗЕВИЙ АСПЕКТ РОЗВИТКУ НАЦІОНАЛЬНОГО ГОСПОДАРСТВА

Selection of previously unsettled parts of the general problem. The analysis of the results of scientific works shows the urgency of the environmental problems of the regions, but despite numerous studies, the question of monitoring the level of modernization of the environmental sphere is at the level of discussions and needs further research and analysis.

The purpose of the article is to monitor the level of the modernization of the ecological sphere and rating the regions of Ukraine on the basis of the developed guideline, which will facilitate the creation of scientific support for the adoption of management decisions aimed at addressing the environmental problems of the regions of Ukraine.

Statement of the main material. Because of the constant economic development coverage of the human economic activity of the entire planet, humanity faces ever more acute environmental problems, both regional and global, both to increase the amount of harmful emissions, and to exhaust natural resources. However, along with the growing probability of a global conflict between human economic activity and the environment, human knowledge about ecological and economic connections increases and the search for practical solutions to existing and potential conflicts continues [1].

Environmental problems significantly limit the socio-economic development of society, which is directly related to the quality of the environment. The development of a balanced system of rational nature management, combined with an adequate structural restructuring of industrial potential, taking into account the minimization of anthropogenic load and ensuring the social security of man, will be the basis for ensuring and stable social development of the state. Therefore, there is an urgent need to define the regions of Ukraine with the worst condition of environmental components, with the purpose of directing financial resources for the implementation of environmental protection measures [3].

The socio-economic development of society is directly related to the quality of the environment at the present stage. Therefore, the ecological policy of Ukraine is aimed at the formation of a balanced system of rational nature management with an adequate structural restructuring of industrial potential in order to minimize anthropogenic load and ensure the social security of man. In order to ensure a stable social development of the country, it is necessary to identify the regions with the worst condition for the purpose of directing financial resources to solve their problems on the basis of the assessment of the environment current state; therefore, the study of modern methods of integrated and integrated environmental assessments is very actual [7, pp. 4-5].

Ecological modernization marks a transition based on complex reforms from not focused on the environment to ecologically oriented society and should become a nation-wide strategy. It allows to decide two fundamentally important groups of tasks: related, firstly, to qualitative changes in the technological base of the economy and its information component, as well as organizational and production factors; secondly, with the transition to a resourceinnovative development strategy. The key elements of environmental modernization are: environmental policy, which should be based on the absence of a conflict between environmental objectives and economic growth, its objectives should become elements of the country's overall policy; the implementation of economic concepts in the mechanisms and principles of environmental policy; technical innovations, the introduction of new industrial technologies through the implementation of government decisions. The forms of ecological modernization aimed at solving environmental problems in conditions of limited and depleted natural resources include environmentally oriented development of industry; technological platforms of ecological development; the ecologization of economic development; introduction and development of clean production and environmental technologies [6]. 
ГАЛУЗЕВИЙ АСПЕКТ РОЗВИТКУ НАЦІОНАЛЬНОГО ГОСПОДАРСТВА

Characteristics of the ecological state of the environment of the regions relies mainly on indicators of various types of emissions, which is determined solely by the existing information base.

The level of the modernization of the ecological sphere is proposed to be calculated as the ratio of the integral indicator of the state of the environment (based on official data of the State Statistics Committee of Ukraine) to its average value in the country. The integral index includes indices of the state of land, water resources and atmospheric air [4-5].

Changes in the location of the regions in 2016 compared to 2015 on the scale of the integral indicator of the environmental situation did not occur (Table 1).

Table 1

Dynamic of the level of modernization of the ecological sphere

\begin{tabular}{|c|c|c|c|c|c|c|}
\hline \multirow{3}{*}{ Region } & \multicolumn{6}{|c|}{ LECS } \\
\hline & \multicolumn{2}{|c|}{2010} & \multicolumn{2}{|c|}{2015} & \multicolumn{2}{|c|}{2016} \\
\hline & $\%$ & rank & $\%$ & rank & $\%$ & rank \\
\hline AR Krym & 89 & 20 & - & - & - & - \\
\hline Vinnytska & 110 & 11 & 97 & 15 & 97 & 15 \\
\hline Volynska & 115 & 3 & 133 & 1 & 133 & 1 \\
\hline Dnipropetrovska & 71 & 24 & 40 & 21 & 40 & 21 \\
\hline Donetska & 38 & 25 & - & - & - & - \\
\hline Zhytomyrska & 115 & 4 & 130 & 2 & 130 & 2 \\
\hline Zakarpatska & 109 & 12 & 130 & 3 & 130 & 3 \\
\hline Zaporizka & 75 & 23 & 32 & 22 & 32 & 22 \\
\hline Ivano-Frankivska & 95 & 17 & 91 & 18 & 91 & 18 \\
\hline Kyivska & 82 & 22 & 95 & 16 & 95 & 16 \\
\hline Kirovohradska & 100 & 15 & 112 & 6 & 112 & 6 \\
\hline Luhanska & 88 & 21 & - & - & - & - \\
\hline Lvivska & 95 & 18 & 104 & 11 & 104 & 11 \\
\hline Mykolaivska & 106 & 13 & 94 & 17 & 94 & 17 \\
\hline Odeska & 92 & 19 & 108 & 9 & 108 & 9 \\
\hline Poltavska & 113 & 8 & 99 & 14 & 99 & 14 \\
\hline Rivnenska & 115 & 5 & 130 & 4 & 130 & 4 \\
\hline Sumska & 99 & 16 & 81 & 19 & 81 & 19 \\
\hline Ternopilska & 118 & 1 & 100 & 13 & 100 & 13 \\
\hline Kharkivska & 103 & 14 & 81 & 20 & 81 & 20 \\
\hline Khersonska & 116 & 2 & 105 & 10 & 105 & 10 \\
\hline Khmelnytska & 115 & 6 & 110 & 8 & 110 & 8 \\
\hline Cherkaska & 112 & 9 & 101 & 12 & 101 & 12 \\
\hline Chernivetska & 114 & 7 & 116 & 5 & 116 & 5 \\
\hline Chernihivska & 112 & 10 & 111 & 7 & 111 & 7 \\
\hline
\end{tabular}

Comment. Data are given without taking into account the temporarily occupied territory of the Autonomous Republic of Crimea, the city of Sevastopol and part of the zone of the anti-terrorist operation.

Source: calculated by the author according to the State Statistics Committee of Ukraine [2; 4;5].

According to the results of the rating assessment of the level of environmental modernization in 2016, we propose to allocate the following 4 groups of regions: regions with a crisis of the LECS, regions with critical LECS, regions with satisfactory LECS, regions with favorable LECS (Fig., Table 2). 


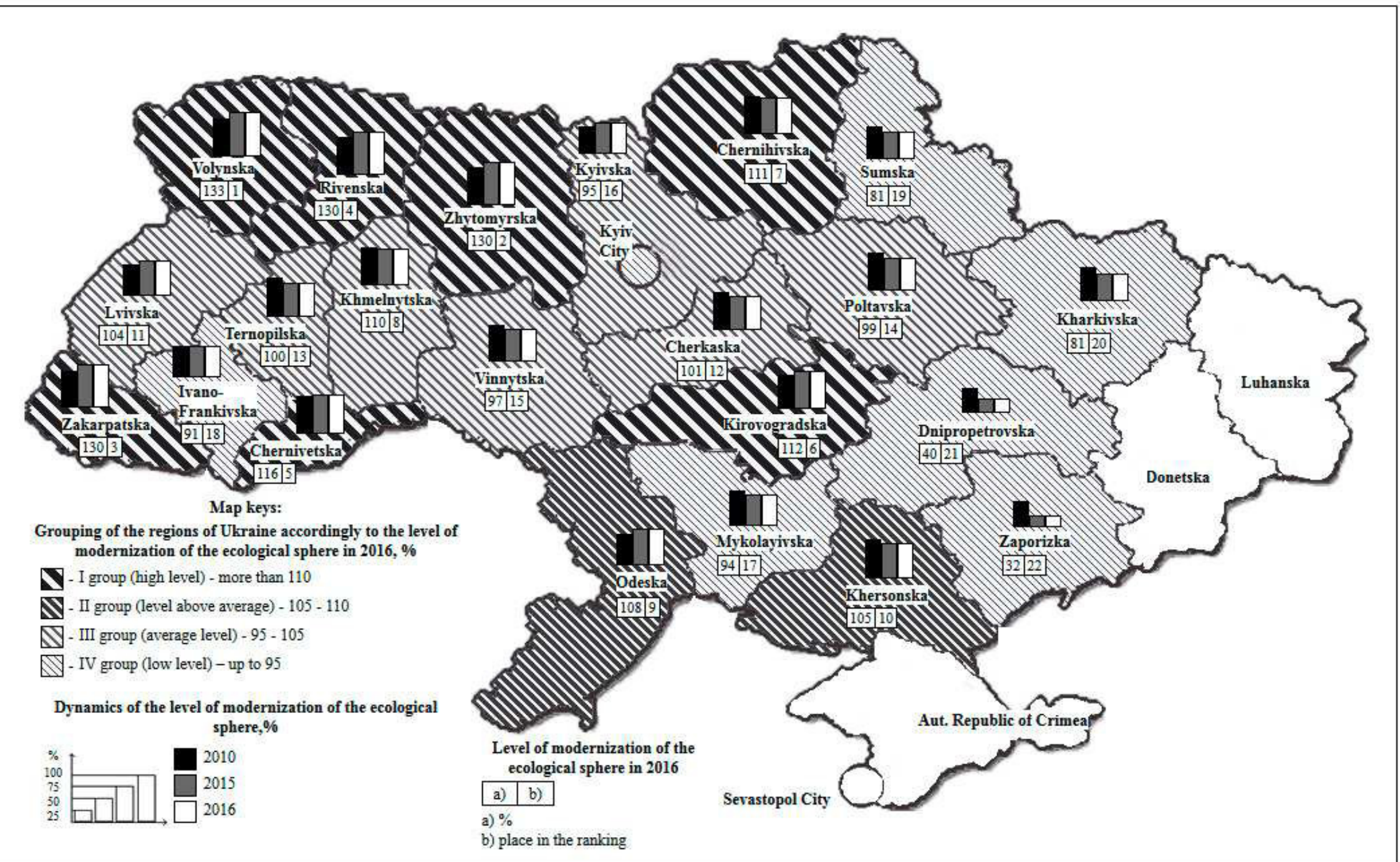

Fig. Grouping of the regions of Ukraine by the level of modernization of the ecological sphere Source: calculated by the author according to the State Statistics Committee of Ukraine $[2 ; 4 ; 5]$. 
ГАЛУЗЕВИЙ АСПЕКТ РОЗВИТКУ НАЦІОНАЛЬНОГО ГОСПОДАРСТВА

The group with favorable level of the modernization of the environmental sphere includes 5 regions: Volynska (133\%), Zhytomyrska (130\%), Zakarpatska (130\%), Rivnenska $(130 \%)$ and Chernivetska $(116 \%)$. The value of the integral indicator in this group varies from 0.554 in Chernivrtska region to 0.636 in the Volynska region.

Table 2

Grouping of the regions according to the level of modernization of the ecological sphere in 2016

\begin{tabular}{|c|c|l|}
\hline Level LECS & Value range & \multicolumn{1}{|c|}{ Regions } \\
\hline Crisis & $<80 \%$ & Dnipropetrovska, Zaporizka \\
\hline Critical & $\geq 80 \%<95 \%$ & Ivano-Frankivska, Mykolaivska, Sumska and Kharkivska \\
\hline Satisfactory & $\geq 95 \%<115 \%$ & $\begin{array}{l}\text { Vinnytska, Kyivska, Kirovohradska, Lvivska, Odeska, Poltavska, } \\
\text { Ternopilska, Khersonska, Khmelnytska, Cherkaska and } \\
\text { Chernihivska }\end{array}$ \\
\hline Favorable & $\geq 115 \%$ & \begin{tabular}{l} 
Volynska, Zhytomyrska, Zakarpatska, Rivnenska and Chernivetska \\
\hline
\end{tabular}
\end{tabular}

Source: $[2 ; 4 ; 5]$.

The group with a satisfactory level of the modernization of the environmental sphere includes half of the regions: Vinnytska (98\%), Kyivska (95\%), Kirovohradska (112\%), Lvivska (104\%), Odeska (108\%), Poltavska (99\%), Ternopilska (100\%), Khersonska (105\%), Khmelnytska (110\%), Cherkaska (101\%), Chernihivska (111\%). The value of the integral indicator in this group varies from 0.455 in Kyivska to 0.534 in the Kirovogradska regions.

The group with the critical level of the modernization of the environmental sphere includes: Ivano-Frankivska (91\%), Mykolaivska (94\%), Sumska (81\%) and Kharkivska $(81 \%)$ regions. The value of the integral indicator in this group ranges from 0.389 in the Kharkivska and Sumska regions to 0.448 in the Mykolaivska region.

The group with the crisis level of the modernization of the environmental sphere included Dnipropetrovska (40\%) and Zaporizhska (32\%) with the values of the integral index 0.189 and 0.154 respectively.

Compared to 2010, regions that significantly increased in the rating are Zakarpatska ( +9 positions), Kyivska ( +6 positions), Kirovogradska ( +9 positions), Lvivska ( +7 positions) and Odeska ( +10 positions) regions. At the same time there are regions which positions declined: Poltavska (-6 positions), Ternopilska (-12 positions), Kharkivska (-6 positions) and Khersonska ( -8 positions) regions.

The decrease of the integral index is due primarily to factors such as the high specific gravity of the residual raw water in its total volume, respectively, in the Odeska region; increased amount of heavy metals in waste water in the Lvivska region; increased nitrogen and sulfur emissions in the Ivano-Frankivska region; a significant amount of emissions of harmful substances from mobile sources of pollution in Odesska and Lvivska regions.

Priority tasks of ecological modernization of socio-economic development include:

- of the legislative framework in the field of environmental protection, aimed at achieving national advantages of environmental modernization and compliance with EU directives, the implementation of multilateral agreements (conventions, protocols, etc.) to which Ukraine is a party, social acceptability, realism, economic efficiency;

- development of a regionally adapted "roadmap" of environmental transformations of social and economic development with a grounded strategy, objectives, implementation mechanism, selection of performers and their tasks, regional priorities;

- ecological restructuring of the economy by reducing the share of "dirty" productions by stimulating the development of knowledge-intensive industries, services, tourism;

- ensure environmentally favorable conditions for the widespread introduction of environmental technologies (resource and energy saving, low-waste, waste disposal) in the production and improve the environmental responsibility of business; 
ГАЛУЗЕВИЙ АСПЕКТ РОЗВИТКУ НАЦІОНАЛЬНОГО ГОСПОДАРСТВА

- prevention of emergency situations of natural and technological nature, provides for the analysis and prediction of environmental risks, based on the results of strategic environmental assessment, state environmental impact assessment, environmental monitoring;

- creation of a national information system for environmental protection;

- mitigation of environmental damage caused by the fighting foreign troops of the aggressor;

- development and implementation of long-term state program of continuous environmental education and training, foster environmental awareness and the development of ecological culture of man's relationship to the natural environment [6].

International experience says that only through the combined efforts of regional authorities and businesses searching effective tools and methods for solving problems of the relationship between society and nature can be ensured compliance of the growing economy to the criteria for sustainable development and to improve the social and environmental well-being of the population. These include eco-directed restructuring of the economy, support and development of high-tech, environmentally friendly and resource-saving production, the use of new environmental policy instruments, including international standards of environmental management, voluntary environmental agreements, ensuring information transparency in decision processes and implementation of environmental-economic and managerial decisions [6].

Conclusions Monitoring of the modernization status of the ecological sphere made it possible to conduct methodologically correct comparisons of the levels of the modernization state on the meso level according to their separate components: indices of the state of land, water resources and atmospheric air. The monitoring will contribute to the creation of scientific support for the adoption of management decisions aimed at solving environmental problems of the regions of Ukraine.

\section{References}

1. Hnatyshyn, M. A. (2010). Stalyi ekoloho-ekonomichnyi rozvytok: evoliutsiia pohliadiv [Sustainable ecological and economic development: evolution of views]. Efektyvna ekonomika Effective economy, 12. Retrieved from http://www.economy.nayka.com.ua/?op=1\&z=409.

2. Karmazina, O. O. (Ed.) (2017). Statystychnyi biuleten "Rehionalnyi liudskyi rozvytok» [Statistical Bulletin "Regional Human Development"]. Kyiv: Derzhavna sluzhba statystyky [in Ukrainian].

3. Obykhod, H. O., Omelianenko, T. L. (2012). Metodychni pidkhody shchodo otsinky rivnia ekolohichnoi nebezpeky rehioniv Ukrainy [Methodical approaches for environmental threat assessment of regions of Ukraine]. Efektyvna ekonomika - Effective economy, 10. Retrieved from http://www.m.nayka.com.ua/?op=1\&j=efektyvna-ekonomika\&s=ua\&z=1429.

4. Popelo, O. V. (2016). Metodychni pidkhody do otsinky rivnia modernizatsii produktyvnykh syl [Methodological approaches to the assessment of the level of modernization of productive forces]. Visnyk Odeskoho natsionalnoho universytetu. Seriia Ekonomika - Bulletin of the Odessa National University. Series Economics, 21 (7-1 (49)), 109-113 [in Ukrainian].

5. Popelo, O. V. (2017). Methodological approaches to modernization processes of the productive forces in the conditions of Eurointegration. Naukovyi Visnyk Polissya - Scientific bulletin of Polissia, 1 (1 (9)), 218-224 [in English].

6. Stepanenko, A. V, Omelchenko, A. A. (2018). Teoretychni aspekty ekolohichnoyi modernizatsiyi ekonomichnoho rozvytku [Theoretical aspects of ecological modernization of economic development]. Ekonomika Ukrainy - Ukraine economy, 1, 40-53 [in Ukrainian].

7. Vasenko, O. H., Rybalova, O. V., Artemiev, S. R. \& Horban, N. S. (2015). Intehralni ta kompleksni otsinky stanu navkolyshnoho pryrodnoho seredovyshcha [Integral and integrated assessments of the state of the environment]. Kharkiv: NUHZU [in Ukrainian].

\section{References (in language original)}

1. Гнатишин M. А. Сталий еколого-економічний розвиток: еволюція поглядів. Ефективна економіка. 2010. № 12. URL: http://www.economy.nayka.com.ua/?op=1\&z=409 (дата звернення: 15.01.2018). 
ГАЛУЗЕВИЙ АСПЕКТ РОЗВИТКУ НАЦІОНАЛЬНОГО ГОСПОДАРСТВА

2. Регіональний людський розвиток: статистичний бюлетень / відп. за вип. О. О. Кармазіна. Київ: Державна служба статистики України, 2017. - 66 с.

3. Обиход Г. О., Омельяненко Т. Л. Методичні підходи щодо оцінки рівня екологічної небезпеки регіонів України. Ефективна економіка. 2012. № 10. URL: http:/www.m.nayka.com.ua/ ?op=1\&j=efektyvna-ekonomika\&s=ua\&z=1429 (дата звернення: 15.01.2018).

4. Попело О. В. Методичні підходи до оцінки рівня модернізації продуктивних сил. Вісник Одеського національного університету. Серія: Економіка. 2016. Т. 21, Вип. 7-1 (49). С. $109-114$.

5. Popelo O. V. Methodological approaches to modernization processes of the productive forces in the conditions of Eurointegration. Науковий вісник Полісся. 2017. Т. 1, № 1 (9). С. 218-224.

6. Степаненко А. В., Омельченко А. А. Теоретичні аспекти екологічної модернізації економічного розвитку. Економіка України. 2018. № 1. С. 40-53.

7. Інтегральні та комплексні оцінки стану навколишнього природного середовища: монографія / О. Г. Васенко та ін. Харків: НУГЗУ, 2015. 419 с.

Popelo Olha - PhD in Economics, Associate Professor, Department of Management and Public Administration,

Chernihiv National University of Technology (95 Shevchenka Str., 14035 Chernihiv, Ukraine).

Попело Ольга Владимировна - кандидат экономических наук, доцент кафедры менеджмента и государственной службы, Черниговский национальный технологический университет (ул. Шевченко, 95, м. Чернигов, 14035, Украина).

Попело Ольга Володимирівна - кандидат економічних наук, доцент кафедри менеджменту та державної служби, Чернігівський національний технологічний університет (вул. Шевченка, 95, г. Чернігів, 14035, Україна).

E-mail: popelo.olha@gmail.com 